\title{
Plot Size Related to Numbers of Treatments and Replications, and Experimental Precision in Conilon Coffee From Clonal Seedlings of LB1
}

\author{
Gleyce Pereira Santos ${ }^{1}$, Karina Tiemi Hassuda dos Santos ${ }^{1}$, Renan Garcia Malikouski ${ }^{2}$, \\ Vinicius de Souza Oliveira ${ }^{2}$, Jéssica Sayuri Hassuda Santos ${ }^{1}$, Marcio Paulo Czepak ${ }^{1}$, Omar Schmildt ${ }^{2}$, \\ Sara Dousseau Arantes ${ }^{2}$, Robson Bonomo ${ }^{1} \&$ Edilson Romais Schmildt ${ }^{1}$ \\ ${ }^{1}$ Departament of Agrarian and Biological Sciences, Federal University of Espírito Santo, São Mateus, ES, Brazil \\ ${ }^{2}$ Postgraduate Program in Tropical Agriculture, Federal University of Espírito Santo, São Mateus, ES, Brazil \\ Correspondence: Gleyce Pereira Santos, Departament of Agrarian and Biological Sciences, Federal University of \\ Espírito Santo, São Mateus, ES, Brazil. E-mail: gleyce.gps@hotmail.com
}

$\begin{array}{lcc}\text { Received: April 1, } 2019 & \text { Accepted: May 16,2019 } & \text { Online Published: July 31, } 2019 \\ \text { doi:10.5539/jas.v11n11p285 } & \text { URL: https://doi.org/10.5539/jas.v11n11p285 }\end{array}$

\begin{abstract}
In the execution of experiments involving agricultural crops, it is essential that the researcher is able to initially establish the outline, the amount of treatments, replication and the plot sizes, to predict the physical space and waste of material. The planning is not always easy due to the lack of research pointing out the adequate plot size, especially in experiments throughout seedlings stage. The objective of this work was to determine the adequate plot size for experiments with conilon coffee clone LB1 seedlings. Fort this Hatheway's suggested methodology was used, in which the coefficient values of variation and the heterogeneity index were obtained through bootstrap simulation with replications. The findings emphasized that in the experiments involving the conilon coffee tree LB1 manufactured in bags, with the delineation in randomized blocks, when the evaluation of destructive characteristics require a larger experimental plot size than when characteristics are non-destructive, considering the same margin error. In the installation of experiments with conilon coffee tree LB1 clone, in randomized blocks with 7 to 40 treatments and three replications, plots holding nine seedlings are enough to identify significant differences between average of treatments of non-destructive kinds to $5 \%$ of prospects and variation between the average of treatments $30 \%$ of overall experimental average. However, for destructive characteristics in randomized blocks with 7 to 40 treatments in three replications, plots holding 14 seedlings are enough to identify significant differences between treatment averages to $5 \%$ of prospects and variation between average treatments $30 \%$ of overall experimental average.
\end{abstract}

Keywords: Coffea canephora Pierre ex Froehner, Hatheway's method, experimental planning, outline in randomized blocks

\section{Introduction}

In field experiments involving conilon coffee trees' enlightenment, varied crop sizes have been found, since only eight plants (Dardengo, Sousa, Reis, \& Gravina, 2013) up until thirty plants per plot (Berilli et al., 2015), however in literature there are no works that report what the adequate plot size is to be used in function of the delineation, number of treatments and replication of experiments.

Experiments involving the growth of the seedlings of conilon coffee trees, in nursery, follow the same arbitrariness present in field experiments, in other words, absence of works in literature that designate adequate plot sizes. Evaluating experiments are reported with plot sizes of two (Dardengo et al., 2013), six (Dias et al., 2009), ten (C. M. Meneghelli, Monaco, Haddade, L. A. M. Meneghelli, \& Krause, 2016), twelve (Silva, Vieira, Viana, \& Barroso, 2010) useful seedlings per plot. It should be noted that the demand for research with seedlings of the conilon coffee tree is substantial on the basis of constant evolution of the productive process, due to the need of evaluation of new substrate, new active principles of pesticides, formulation of slow release manure, among others. Therefore, the ascertainment of plot sizes based on scientific criteria is of extreme significance to allow for more credibility towards experimental results (Storck, Garcia, Lopes, \& Estefanel, 2011). 
As to the characteristics under evaluation, the researcher could be interested in evaluating easy-to-measure characteristics, that normally do not involve destruction of seedlings (Silva et al., 2010; Buffon et al., 2016), to which is also utilized by manufacturers for clone selection, or in characteristics that include the destruction of seedlings as dry matter of the aerial and of the root system (Dias et al., 2009; Firmino, Cogo, Almeida, Campos, \& Morais, 2012; Dardengo et al., 2013).

To obtain the adequate plot size, are described in literature dozens of methodologies, and among these are distinguished by their frequent use, currently, the maximum modified curvature, according to Meier and Lessman (1970), that of the maximum curvature of the varient's coefficient (Paranaíba, Ferreira, \& Morais, 2009), and, that of Hatheway (1961). According to Celanti, Schmildt, Alexandre, Cattaneo, and Schmildt (2016b), the use of Hatheway's methodology is interesting because it can satisfy the yearnings of the researcher who wishes to know the adequate plot size for their research accuracy, that includes the number of treatments and replications, the experimental outline used and the experiments precision. Among recent uses of Hatheway's methodology are mentioned those of Cargnelutti Filho et al. (2018) in determining the plot size in experiments with Pigeon pea and that of Schmildt et al. (2018) with papaya tree genotypes.

The colinon coffee tree is a diploid plant that contains a gametophytic auto incompatibility, yet, the plants obtained through seminiferous methods are very distinctive among one another, although the propagated plants in vegetative form are genetically alike, thus making it homogenous production (Bragança, Carvalho, Fonseca, \& Ferrão, 2001). The seminiferous propagation is done with the intent to obtain new varieties, these plants being selected by standing out among the others. After the assortment the propagation is done in the vegetative state, in order to maintain the traits of the parent plant, or carry out the genetic improvement of said variety, and thus are obtained the clones of the conilon coffee tree utilized in the composition of clonal varieties (Ferrão et al., 2012). Among many clones of the conilon coffee tree, LB1 has been widely utilized by many rural producers and farmers from upstate in the composition of their clonal varieties, this happens by the fact that the clone shows excellent results in production fields by being compatible with other clones utilized in the variety. Thus, the LB1 clone being evaluated in the field, north of the state of Espírito Santo, closely with other clones for the formation of other clonal varieties (Oliosi, Dalazen, Covre, Silva, \& Partelli, 2018).

Against the subject, was objectified by this assignment the ascertainment of the adequate plot size for experiments involving the seedlings of the conilon coffee tree (Coffea canephora Pierre ex Froehner), LB1 clone, by the methods suggested by Hatheway (1961) using bootstrap simulation.

\section{Material and Methods}

For the fulfillment of this current study 160 seedlings of the conilon coffee tree LB1 clone (Coffea canephora Pierre ex Froehner) were used, acquired along with the Candeias nursery, located upstate in Espírito Santo, Brazil, with the South latitude of $18.9107124^{\circ}$ and West longitude of $40.0532683^{\circ}$. The region's climate is labeled as Aw, (Alvares, Stape, Sentelhas, Gonçalves, \& Sparovek, 2014). The nursery features coverage with polyolefins screens $\left(\right.$ Sombrite ${ }^{\circledR}$ ), enabling the entry of $50 \%$ of solar lighting. The irrigation was done intermittently by means of a localized system of micro sprinklers.

The seedlings were derivative from stakes of orthotropic branches, these being standardized with nearly $10 \mathrm{~cm}$ of length, rendering only one pair of leaves each. The seedlings were produced in polypropylene bags with $11 \mathrm{~cm}$ of width $\times 20 \mathrm{~cm}$ of height, thickness of $0.006 \mathrm{~cm}$ and approximately $770 \mathrm{~mL}$ of substrate. The bags were filled with conventional substrate, composed of underground soil and cattle manure hardened in the ratio $4: 1$. Phosphate fertilizations were done 30 days after stacking and two foliar fertilizations with micronutrients, one at 45 days and the other 75 days after stacking.

90 days after stacking, the seedlings were moved to the plant breeding laboratory at the University Center in Upstate Espirito Santo/UFES, where the non-destructive characteristics were evaluated: height of the aerial part (HAP), measured with a ruler graduated in $\mathrm{cm}$, measuring from base of the stalk until the insertion of the last leaf; number of leaves (NL), by counting all leaves in each of the plant seedlings; diameter of the collect (DC), measured with a digital calliper at three $\mathrm{cm}$ from the substrate surface in $\mathrm{mm}$; foliar area per seedlings (FA), scanned with portable scanner Vupoint ${ }^{\mathbb{B}}$ Solutions Magic Wand PDS-ST415-VPS and measured with the aid of Software Image ${ }^{\circledR}$ (Schindelin, Rueden, Hiner, \& Eliceiri, 2015). After these procedures, the seedlings have the substrate removed in running water and were separated by aerial part and the root of each individual and properly identified seedling, then the seedlings were taken to the closed ventilation greenhouse at $60^{\circ} \mathrm{C}$ until the constant mass was reached for evaluation of the destructive characteristics: dry matter by aerial part (DMAP), in $\mathrm{g}$; total dry matter (TDM), and dry matter by root (DMR) by the difference between TDM and DMAP; and, quality index of Dickson's seedlings (DQI) given by Equation 1 (Dickson, Leaf, \& Hosner, 1960). 


$$
\mathrm{DQI}=\mathrm{TDM} /\{(\mathrm{HAP} / \mathrm{DC})+(\mathrm{DMAP} / \mathrm{DMR})\}
$$

In the sampling of 160 seedlings evaluated for each of the characteristics, the following descriptive statistics were determined: minimum, maximum, mean, standard deviation, coefficient of variation $(\mathrm{CV}$, in \%) and normalcy of data by the Shapiro-Wilk test. For the determination of the adequate plot size $\left(\mathrm{X}_{0}\right)$ Hatheway's method (1961) was used, under Equation 2.

$$
\mathrm{X}_{0}=\sqrt[b]{2\left(\mathrm{t}_{1}+\mathrm{t}_{2}\right)^{2} \mathrm{CV}^{2} / \mathrm{rd}^{2}}
$$

where, the coefficient values of heterogeneity (b) and the coefficient of variation (CV) for each characteristic, were obtained for bootstrap simulation, with 2000 re-samplings, according to Celanti, Schmildt, Schmildt, Alexandre, and Cattaneo (2016a); $d$ is the experimental precision, understand the difference between means of treatment detected as significant $5 \%$ of probability, expressed in percentage of the uniformity test's overall average; $t_{1}$ is the tabled value of $t$ for tests of significance (bilateral test to $5 \%$ ), with df degrees of freedom; $t_{2}$ is the tabled value of $t$, bilateral, corresponding to one error of $2(1-p)$, with df degrees of freedom, being $p=0.80$ the probability of obtaining significant results. The values of tabled distribution of $t$ were obtained with df degrees of freedom of the residue, in order for the I treatments and $r$ replications, being $\mathrm{dl}=(\mathrm{I}-1) \cdot(\mathrm{r}-1)$ for experiments in randomized blocks.

When the researcher evaluates the experiment, they will be able to analyze multiple characteristics, destructive and/or non-destructive. Each characteristic could demand a different plot size $\left(\mathrm{X}_{0}\right)$, as displayed in multiple scientific projects (Boyhan, 2013; Celanti et al., 2016a, 2016b; E. R. Schmildt, O. Schmildt, Cruz, Cattaneo, \& Ferreguetti, 2016), and, therefore, evaluating several characteristics there will be several plot sizes. However, when the researcher sets up the experiment, they will have to establish only one plot size. In this Project, the determination of the plot size, is in function of the $\mathrm{CV}$ value of the seedlings sample. The determination of $\mathrm{X}_{0}$ was done for one non-destructive characteristic only, one of larger $\mathrm{CV}$ among the non-destructive characteristics, in case the researcher is interested only in the non-destructive characteristics, and, a destructive characteristic, the one with larger CV among the destructive characteristics, in case the researcher is interested in only the destructive characteristics. This is valid because, once the researcher used Hatheway's method (1961), with bootstrap simulation, the only unknown will be the CV contained in Equation 2, that depends on which characteristic is under evaluation, seen as the precision $d$ and the number of replications $r$ are defined by the researcher, the values of $t$ are tabled and fixed depending on the number of treatments and replications and, the index value of heterogeneity $b$ is next to unit, as demonstrated by Celanti et al. (2016a).

The data was analyzed using the computerized resources from the R Software (R Development Core Team, 2019). Because it is a discrete random variable, the adequate plot size was displayed as a whole number, rounding up to the next integer (Celanti et al., 2016a).

\section{Results and Discussion}

Image 1 illustrates the conilon (Coffea canephora Pierre ex Froehner) coffee tree seedlings, LB1 clone, by occasion of evaluations in January 2018, at 90 days after the stacking. These seedlings were, on average, 11.82 $\mathrm{cm}$ tall by aerial part (Table 1), similar to what was verified by other researchers (Dardengo et al., 2013) and considered of good standard, by seedling producers and farmers, to take to the field for planting. The diameter for the medium collects obtained was of $6.78 \mathrm{~mm}$, this being nearly double of what was found by Silva et al. (2010), this can be explained due to the difference shown among conilon coffee clones, thus showing the developing potential of the LB1 clone plant. Each seedling had on average approximately 8 leaves per plant, that being very close to the results found by Berilli et al. (2018). The average foliar area of $203.56 \mathrm{~cm}^{2}$ per plant is close to the average area $186.86 \mathrm{~cm}^{2}$ described by Espindula, Jaraceski, Teixeira, Campanharo, and Dias (2015). 


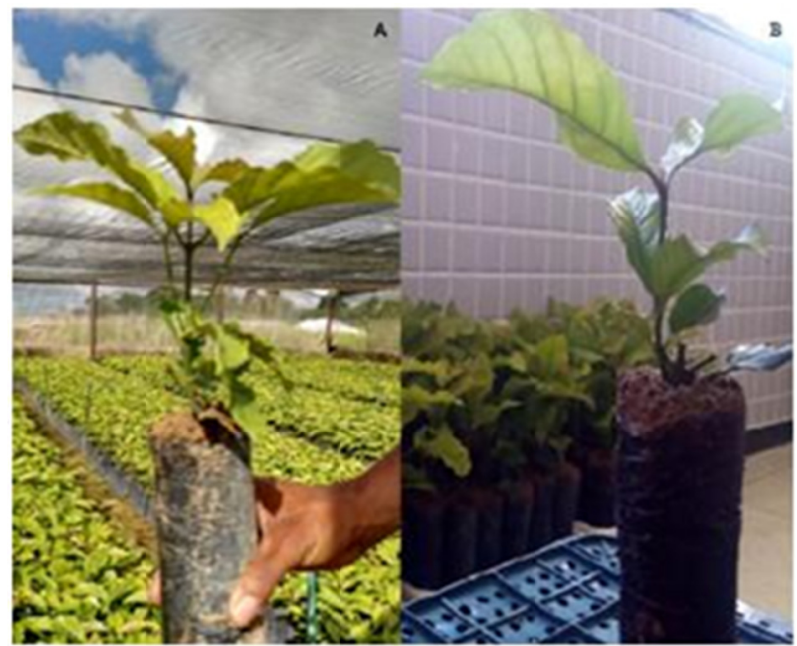

Figure 1. Conilon coffee tree (Coffea canephora Pierre ex Froehner), LB1 clone, evaluated 90 days after the stacking ( $\mathrm{A}=$ Seedlings in nursery; $\mathrm{B}=$ Seedlings in the breeding lab for the attainment of evaluations)

As for the destructive characteristics, the quality evaluation showed the average value of DQI $=0.68$ (Table 1 ), similar to what was observed by Dardengo et al. (2013), that found the value of DQI $=0.60$. In the evaluation of the conilon coffee tree the average value of TDM found was of $3.22 \mathrm{~g}$, the same way that the values of DQI presented similar to the ones by Dardengo et al. (2013), that being of $2.99 \mathrm{~g}$, which according to the same represents a good level of development for the plant. The dry matter of the aerial part presented the average of $2.41 \mathrm{~g}$, that being superior to the value of $1.28 \mathrm{~g}$ found by Espindula et al. (2015) and inferior to the value of $3.6 \mathrm{~g}$ found by Berilli et al. (2018). The dry matter from the root had the average of $0.81 \mathrm{~g}$, with the average value close to what was found by Berilli et al. (2018), that being of $0.99 \mathrm{~g}$, appointed by the same as representative of good radicular development of the plant.

Pertaining the variability of the data, measured by the coefficient of variation (CV), among the eight characteristics the one that presented minor dispersion was the diameter of the collect $(\mathrm{CV}=16.67 \%)$ and the one that presented the most was the dry matter of the roots (DMR) with $\mathrm{CV}=43.87 \%$ (Table 1). Among the non-destructive characteristics, the one with the largest number of leaves (NL), with $\mathrm{VC}=35.27 \%$. By the incorporated criteria in this article, was done the determination of sample sizes for the non-destructive characteristics through the NL and, for the destructive characteristics, through the DMR. This procedure of adopting the larger value of $\mathrm{CV}$ among all the values presented, was also adopted by other researchers in tasks for the determination of the plot size for better apprehension of the variability of data (Cargnelutti Filho et al., 2018; Lavezo et al., 2018).

Regarding the distribution of probability of the data, it is observed that only the characteristics HAP and FA present standard distribution, according to the Shapiro-Wilk test (Table 1). Considering that most of the characteristics evaluated, including the ones used for determination of plot sizes, there is no standard distribution of the sample data, the use of Hatheway's (1961) with bootstrap simulation with the replication of the data, shows itself most appropriate. The use of simulation can be done adequately for any type of probability of distribution, seen as the simulation leads to the normalcy of the data, as appointed by González et al. (2017) and established for DMR in Image 2, which the test of standard distribution by Shapiro-Wilk shows $p=0.462$. By the results presented to the characteristics evaluated in the LB1 seedlings, it is noted that the same are adequate for this type of research. 
Table 1. Descriptive statistics with the values for minimum, maximum, average, standard deviation (SD), coefficient of variation (CV) and the value $p$ of the normalcy by Shapiro-Wilk (SW) starting at 160 cloned seedlings of the conilon coffee tree (Coffea canephora Pierre ex Froehner), LB1 clone, evaluated 90 days after the stacking

\begin{tabular}{lllllll}
\hline Characteristic $^{1}$ & Minimum & Maximum & Average & SD & VC(\%) & SW $^{2}$ \\
\hline Non-destructive & & & & & & \\
HAP & 4.80 & 18.20 & 11.82 & 2.89 & 24.51 & 0.08 \\
DC & 4.60 & 9.52 & 6.78 & 1.13 & 16.67 & $<0.01$ \\
NL & 4.00 & 16.00 & 7.56 & 2.68 & 35.27 & $<0.01$ \\
FA & 68.48 & 366.87 & 203.56 & 60.01 & 29.48 & 0.19 \\
\hdashline Destructive & 1.18 & 4.90 & 2.41 & 0.80 & 32.92 & $<0.01$ \\
DMAP & 0.23 & 2.35 & 0.81 & 0.35 & 43.87 & $<0.01$ \\
DMR & 1.67 & 6.94 & 3.22 & 1.06 & 32.76 & $<0.01$ \\
TDM & 0.22 & 2.01 & 0.68 & 0.29 & 43.36 & $<0.01$ \\
DQI & n & & & & & \\
\hline
\end{tabular}

Note. ${ }^{1}$ HAP, aerial part height in $\mathrm{cm}$; DC, diameter of the collect in $\mathrm{mm}$; NL, number of leaves by plant; FA, foliar area in $\mathrm{cm}^{2}$; DMAP, dry matter of the aerial part $\mathrm{g}$; DMR, dry matter of the root part $\mathrm{g}$; TDM, total dry matter g; DQI, Dickson's quality index.

${ }^{2}$ Value of $\mathrm{p}$ larger than 0.05 indicates standard distribution of the data by Shapiro-Wilk's test of normalcy.

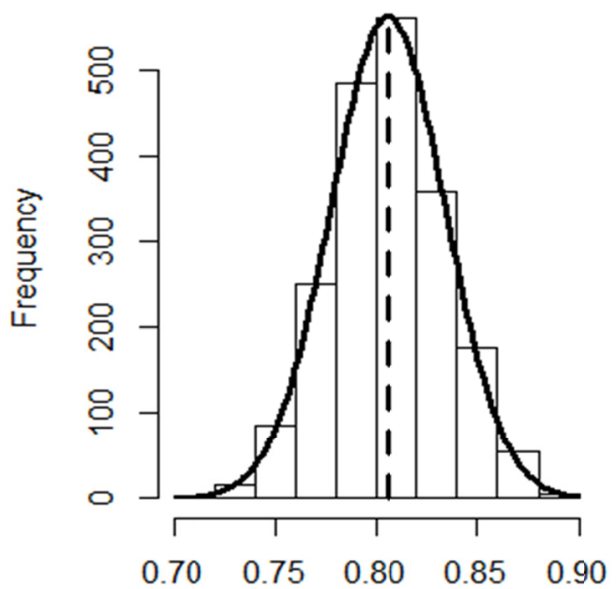

Root dry matter

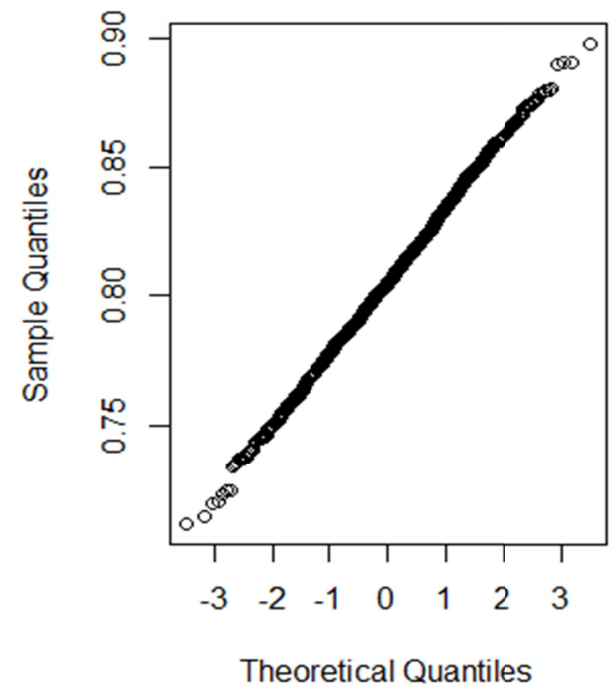

Theoretical Quantiles

Figure 2. Distribution in the frequency of 2000 estimation of the average of dry matter of the roots in $\mathrm{g}$, of the conilon coffee tree LB1 clone and graph quantil-quantil for verification of its normalcy, from a sample of 160 seedlings

The plot size for the number of leaves by seedlings characteristic of the conilon coffee tree LB1 clone produced in bags is shown in Table 2. This table can be accessed in case the researcher is interested in evaluating only non-destructive characteristics. This way, if the researcher were to initiate an experiment with the LB1 seedlings, with five treatments and four replications, in a lining of randomized blocks, and considered a percentage error of $20 \%$ in average, they will use 15 seedlings per plot and, therefore, the experiment will be arranged with the use of 300 seedlings $(5 \times 4 \times 15=300)$. Considering the other characteristics are non-destructive, AP, DC and FA possess a smaller CV regarding the NL (Table 1), these characteristics will have a larger experimental precision, with lower average differences to $20 \%$. This difference is in the precision among the characteristics, and does not constitute a problem since, in practice, what the researcher needs to decide is what is the adequate plot size to install in the experiment. 
Table 2. Adequate plot size $\left(\mathrm{X}_{0}\right)$, expressed in number of plants, for the evaluation of number of leaves, estimated by Hatheway's method in experiments in block delineation at random in different scenarios formed by combinations between the number of treatments (I) and number of replications (J) in Conilon coffee seedlings (Coffea canephora Pierre ex Froehner), LB1 clone, with an margin error of 10\%, 20\%, 30\% and $40 \%$ around the average, and the coefficient of variation $(\mathrm{CV}=35.27 \%)$ evaluated 90 days after the stacking

\begin{tabular}{|c|c|c|c|c|c|c|c|c|c|c|c|}
\hline I & $\mathrm{J}$ & $\mathrm{d}=10 \%$ & $\mathrm{~d}=20 \%$ & $\mathrm{~d}=30 \%$ & $\mathrm{~d}=40 \%$ & I & $\mathrm{J}$ & $\mathrm{d}=10 \%$ & $\mathrm{~d}=20 \%$ & $\mathrm{~d}=30 \%$ & $\mathrm{~d}=40 \%$ \\
\hline 3 & 7 & 34 & 9 & 4 & 3 & 15 & 2 & 76 & 19 & 9 & 5 \\
\hline 4 & 5 & 47 & 12 & 6 & 3 & 15 & 3 & 71 & 18 & 8 & 5 \\
\hline 4 & 6 & 38 & 10 & 5 & 3 & 15 & 4 & 52 & 13 & 6 & 4 \\
\hline 4 & 7 & 32 & 8 & 4 & 2 & 15 & 5 & 41 & 11 & 5 & 3 \\
\hline 5 & 4 & 59 & 15 & 7 & 4 & 15 & 6 & 34 & 9 & 4 & 3 \\
\hline 5 & 5 & 45 & 12 & 5 & 3 & 15 & 7 & 29 & 8 & 4 & 2 \\
\hline 5 & 6 & 37 & 10 & 5 & 3 & 20 & 2 & 73 & 19 & 9 & 5 \\
\hline 5 & 7 & 31 & 8 & 4 & 2 & 20 & 3 & 69 & 18 & 8 & 5 \\
\hline 6 & 4 & 57 & 15 & 7 & 4 & 20 & 4 & 51 & 13 & 6 & 4 \\
\hline 6 & 5 & 44 & 11 & 5 & 3 & 20 & 5 & 41 & 11 & 5 & 3 \\
\hline 6 & 6 & 36 & 9 & 4 & 3 & 20 & 6 & 34 & 9 & 4 & 3 \\
\hline 6 & 7 & 30 & 8 & 4 & 2 & 20 & 7 & 29 & 8 & 4 & 2 \\
\hline 7 & 3 & 78 & 20 & 9 & 5 & 25 & 2 & 72 & 18 & 8 & 5 \\
\hline 7 & 4 & 55 & 14 & 7 & 4 & 25 & 3 & 69 & 18 & 8 & 5 \\
\hline 7 & 5 & 43 & 11 & 5 & 3 & 25 & 4 & 51 & 13 & 6 & 4 \\
\hline 7 & 6 & 35 & 9 & 4 & 3 & 25 & 5 & 41 & 11 & 5 & 3 \\
\hline 7 & 7 & 30 & 8 & 4 & 2 & 25 & 6 & 34 & 9 & 4 & 3 \\
\hline 8 & 3 & 76 & 19 & 9 & 5 & 25 & 7 & 29 & 8 & 4 & 2 \\
\hline 8 & 4 & 55 & 14 & 7 & 4 & 30 & 2 & 71 & 18 & 8 & 5 \\
\hline 8 & 5 & 43 & 11 & 5 & 3 & 30 & 3 & 68 & 17 & 8 & 5 \\
\hline 8 & 6 & 35 & 9 & 4 & 3 & 30 & 4 & 51 & 13 & 6 & 4 \\
\hline 8 & 7 & 30 & 8 & 4 & 2 & 30 & 5 & 40 & 10 & 5 & 3 \\
\hline 9 & 3 & 75 & 19 & 9 & 5 & 30 & 6 & 34 & 9 & 4 & 3 \\
\hline 9 & 4 & 54 & 14 & 6 & 4 & 30 & 7 & 29 & 8 & 4 & 2 \\
\hline 9 & 5 & 42 & 11 & 5 & 3 & 35 & 2 & 70 & 18 & 8 & 5 \\
\hline 9 & 6 & 35 & 9 & 4 & 3 & 35 & 3 & 68 & 17 & 8 & 5 \\
\hline 9 & 7 & 30 & 8 & 4 & 2 & 35 & 4 & 51 & 13 & 6 & 4 \\
\hline 10 & 2 & 83 & 21 & 10 & 6 & 35 & 5 & 40 & 10 & 5 & 3 \\
\hline 10 & 3 & 74 & 19 & 9 & 5 & 35 & 6 & 34 & 9 & 4 & 3 \\
\hline 10 & 4 & 53 & 14 & 6 & 4 & 35 & 7 & 29 & 8 & 4 & 2 \\
\hline 10 & 5 & 42 & 11 & 5 & 3 & 40 & 2 & 69 & 18 & 8 & 5 \\
\hline 10 & 6 & 35 & 9 & 4 & 3 & 40 & 3 & 68 & 17 & 8 & 5 \\
\hline 10 & 7 & 30 & 8 & 4 & 2 & 40 & 4 & 50 & 13 & 6 & 4 \\
\hline
\end{tabular}

When the focus of the experiment is the evaluation of non-destructive characteristics, the researcher must resort to Table 3, that shows the plot sizes in scenarios involving different treatments and different numbers of replications in different experimental precisions. Considering the same scenario appointed previously, of experiments in randomized blocks with five treatments and four replications and precision of $20 \%$ of error on average, the plot size will be 23 seedlings, which corresponds to the use of o 460 seedlings $(5 \times 4 \times 23=460)$ in said experiment, the size being way larger than the one with the use of non-destructive characteristics. Different sample sized for different types of characteristics have also been verified by other crops by other authors in the evaluation of seedlings such as the one by Firmino et al. (2012) with nine plants in the evaluation of seedlings of the Arabica coffee tree and by Celanti et al. (2016b) with five plants in the evaluation of the seedlings of papaya. 
Table 3. Adequate plot size $\left(\mathrm{X}_{0}\right)$, expressed in number of plants, for the evaluation of dry matter from roots, estimated by Hatheway's method in experiments with block delineation at random in different scenarios formed by combination between number of treatments (I) and number of replications (J) in conilon coffee tree seedlings (Coffea canephora Pierre ex Froehner), LB1 clone, with a margin error of 10\%, 20\%,30\% and $40 \%$ around the average, and the coefficient of variation $(\mathrm{CV}=43.87 \%)$ evaluated 90 days after the stacking

\begin{tabular}{|c|c|c|c|c|c|c|c|c|c|c|c|}
\hline I & $\mathrm{J}$ & $\mathrm{d}=10 \%$ & $\mathrm{~d}=20 \%$ & $\mathrm{~d}=30 \%$ & $\mathrm{~d}=40 \%$ & I & $\mathrm{J}$ & $\mathrm{d}=10 \%$ & $\mathrm{~d}=20 \%$ & $\mathrm{~d}=30 \%$ & $\mathrm{~d}=40 \%$ \\
\hline 3 & 7 & 52 & 13 & 6 & 4 & 15 & 2 & 117 & 30 & 13 & 8 \\
\hline 4 & 5 & 72 & 18 & 8 & 5 & 15 & 3 & 109 & 28 & 13 & 7 \\
\hline 4 & 6 & 58 & 15 & 7 & 4 & 15 & 4 & 80 & 20 & 9 & 5 \\
\hline 4 & 7 & 49 & 13 & 6 & 4 & 15 & 5 & 63 & 16 & 7 & 4 \\
\hline 5 & 4 & 90 & 23 & 10 & 6 & 15 & 6 & 52 & 13 & 6 & 4 \\
\hline 5 & 5 & 69 & 18 & 8 & 5 & 15 & 7 & 45 & 12 & 5 & 3 \\
\hline 5 & 6 & 56 & 14 & 7 & 4 & 20 & 2 & 113 & 29 & 13 & 8 \\
\hline 5 & 7 & 47 & 12 & 6 & 3 & 20 & 3 & 107 & 27 & 12 & 7 \\
\hline 6 & 4 & 87 & 22 & 10 & 6 & 20 & 4 & 79 & 20 & 9 & 5 \\
\hline 6 & 5 & 67 & 17 & 8 & 5 & 20 & 5 & 63 & 16 & 7 & 4 \\
\hline 6 & 6 & 55 & 14 & 7 & 4 & 20 & 6 & 52 & 13 & 6 & 4 \\
\hline 6 & 7 & 47 & 12 & 6 & 3 & 20 & 7 & 44 & 11 & 5 & 3 \\
\hline 7 & 3 & 120 & 30 & 14 & 8 & 25 & 2 & 110 & 28 & 13 & 7 \\
\hline 7 & 4 & 85 & 22 & 10 & 6 & 25 & 3 & 106 & 27 & 12 & 7 \\
\hline 7 & 5 & 66 & 17 & 8 & 5 & 25 & 4 & 78 & 20 & 9 & 5 \\
\hline 7 & 6 & 54 & 14 & 6 & 4 & 25 & 5 & 62 & 16 & 7 & 4 \\
\hline 7 & 7 & 46 & 12 & 6 & 3 & 25 & 6 & 52 & 13 & 6 & 4 \\
\hline 8 & 3 & 117 & 30 & 13 & 8 & 25 & 7 & 44 & 11 & 5 & 3 \\
\hline 8 & 4 & 84 & 21 & 10 & 6 & 30 & 2 & 108 & 27 & 12 & 7 \\
\hline 8 & 5 & 65 & 17 & 8 & 5 & 30 & 3 & 105 & 27 & 12 & 7 \\
\hline 8 & 6 & 54 & 14 & 6 & 4 & 30 & 4 & 78 & 20 & 9 & 5 \\
\hline 8 & 7 & 46 & 12 & 6 & 3 & 30 & 5 & 62 & 16 & 7 & 4 \\
\hline 9 & 3 & 115 & 29 & 13 & 8 & 30 & 6 & 52 & 13 & 6 & 4 \\
\hline 9 & 4 & 83 & 21 & 10 & 6 & 30 & 7 & 44 & 11 & 5 & 3 \\
\hline 9 & 5 & 65 & 17 & 8 & 5 & 35 & 2 & 107 & 27 & 12 & 7 \\
\hline 9 & 6 & 53 & 14 & 6 & 4 & 35 & 3 & 104 & 26 & 12 & 7 \\
\hline 9 & 7 & 46 & 12 & 6 & 3 & 35 & 4 & 78 & 20 & 9 & 5 \\
\hline 10 & 2 & 128 & 32 & 15 & 8 & 35 & 5 & 62 & 16 & 7 & 4 \\
\hline 10 & 3 & 113 & 29 & 13 & 8 & 35 & 6 & 51 & 13 & 6 & 4 \\
\hline 10 & 4 & 82 & 21 & 10 & 6 & 35 & 7 & 44 & 11 & 5 & 3 \\
\hline 10 & 5 & 64 & 16 & 8 & 4 & 40 & 2 & 107 & 27 & 12 & 7 \\
\hline 10 & 6 & 53 & 14 & 6 & 4 & 40 & 3 & 104 & 26 & 12 & 7 \\
\hline 10 & 7 & 45 & 12 & 5 & 3 & 40 & 4 & 77 & 20 & 9 & 5 \\
\hline
\end{tabular}

Other important information for the experimenter pertains to the economy as the waste of seedlings in the installation of the experiment. Becoming as a base, once again the plot with the error of $20 \%$ on average, to evaluate destructive characteristics in the seedlings (Table 3), if the researcher installs the experiment considering the minimum number of 20 plots, according to Pimentel-Gomes (2009), they can do with the use of four treatments and five replications, being necessary 18 seedlings per plot and, therefore, waste of 360 seedlings $(4 \times 5 \times 18=360)$. If said experiment consists of five treatments and four replications, 23 seedlings per plot will be necessary, with the waste of 460 seedlings $(5 \times 4 \times 23=460)$. If in the same experiment, ten treatments and two replications were used, the number of seedlings per plot peaks to 32 , and the waste to 640 seedlings $(10 \times 2$ $\times 32=640$ ) for said experiment. It should be noted that, with the same number of plots, the minimum waste is with the combination that allows for the larger number of replications. Such a finding has also been made by other researchers in other studies for the determination of the plot size using Hatheways's methodology (1961), like in pigeon pea (Cargnelutti Filho et al., 2018) and in papaya trees in the field (Schmildt et al., 2018).

Another finding of this experiment analysis is that if the researcher maintains the same number of treatments and increases the number of replications, it will automatically raise the total number of plots, however, will decrease the waste of seedlings to install the experiment. This finding can be proven, once again with the destructive 
characteristics shown in Table 3. This way, if the researcher needs to install the experiment with five treatments, they could use four, five, six or more replications. If the researcher choses the error of $20 \%$ on average, and, uses four replications, 23 seedlings per crop will be necessary, with the waste of 460 seedlings as shown previously. In case they use the same five treatments and increase the number of replications to six, 14 seedlings per plot will be used and will have a waste of 420 seedlings $(5 \times 6 \times 14=420)$ to install the same experiment, a decrease of 40 seedlings in the installation of the experiment, that entails not only the reduction of, but also the space in the seedling production nursery. Similar results were achieved by Schmildt et al. (2018) in the evaluation of papaya tree plants in the field.

By way of orientation of the researcher, the plot size is not so influenced by the variation of the number of treatments. Therefore, if the researcher wishes to install an experiment to evaluate only the non-destructive characteristics and use an error of $30 \%$ on average, with 7 treatments and fixating the number of replications in three, they will have the waste of 9 plants per plot and, if raising the number of treatments to 40 , with the same 3 replications, the waste will be 8 seedlings per plot (Table 2). This type of finding was also made by other researchers in other agricultural crops (Cargnelutti Filho et al., 2018; Schmildt et al., 2018).

In literature were not found works involving research with the use seedlings from the conilon coffee tree LB1 clone, although the same is used frequently by farmers in upstate Espírito Santo and is constituent to the clonal varieties under evaluation (Oliosi et al., 2018). Then, became the freedom to refer to other works using the conilon clones and verify that the plot sizes is between six and twelve seedlings (Dias et al. 2009; Silva et al., 2010; Dardengo et al., 2013), which, referring to Table 3, verifies that falls into the situations se with the error between 30 and $40 \%$ on average. Thus, emphasizing that, no researcher can be accused delineating their experiment incorrectly, solely for using more or less seedlings per crop, it is only understood that for a larger experimental precision, a larger waste of seedlings is required and, for a smaller precision, requires a smaller waste of seedlings. As an illustration of this, consider the non-destructive characteristics shown in Table 2. If the researcher needs to install an experiment with five treatments and chooses to use seven replications, if the same considers an error of $10 \%$ on average, the plot will have 31 seedlings, but in case a smaller precision is wanted, like $40 \%$ of error on average, only two seedlings are needed per plot.

This work contributes to the experimentation with seedlings of the coffee tree LB1 clone produced in polypropylene bags. It is encouraged to verify the plot size for other conilon clones, the same as for the LB1 produced in other types of containers like tubes.

\section{Conclusion}

In the installation of experiments with the conilon coffee tree LB1 clone produced in polypropylene bags, in experiments with randomized blocks, when the evaluation of destructive characteristics requires a larger size of the experimental plot than the non-destructive characteristics, considering the same margin error.

In the installation of experiments with the conilon coffee tree LB1 clone, in randomized blocks with 7 to 40 treatments and three replications, the plots containing nine seedlings are enough to identify the significant differences between averages of treatments about non-destructive characters to $5 \%$ of probability and difference between averages of treatments $30 \%$ of the overall experimental average.

However, in randomized blocks with 7 to 40 treatments and three replications, the plots containing 14 seedlings are enough to identify the significant differences between averages of treatment about destructive characters to $5 \%$ of probability and difference between averages of treatments $30 \%$ of the overall experimental average.

\section{References}

Alvares, C. A., Stape, J. L., Sentelhas, P. C., Gonçalves, J. L. M., \& Sparovek, G. (2014). Köppen's climate classification map for Brazil. Meteorologische Zeitschrift, 22(6), 711-728. https://doi.org/10.1127/ 0941-2948/2013/0507

Berilli, S. S., Berilli, A. P. C. G., Carvalho, A. J. C., Freitas, S. J., Cunha, M., \& Fontes, P. S. F. (2015). Níveis de cromo em mudas de café conilon desenvolvidas em substrato com lodo de curtume como adubação alternativa. Coffee Science, 10(3), 320-328.

Berilli, S. S., Zooca, A. A. F., Ferraz, T. M., Figueiredo, F. A. M. M. A., Rodrigues, W. P., Berilli, A. P. C. G., \& Campostrini, E. (2018). Influence of tannery wastewater sludge doses on biometric and chlorophyll fluorescence parameters in conilon coffee. Biosciência Journal, 34(3), 556-564. https://doi.org/10.14393/ BJ-v34n3a2018-36994

Boyhan, G. E. (2013). Optimum plot size and number of replications for determining watermelon yield, fruit size, 
fruit firmness, and soluble solids. Hortscience, 48(9), 1200-1208. https://doi.org/10.21273/HORTSCI. 48.9.1200

Bragança, S. M., Carvalho, C. H. S., Fonseca, A. F. A., \& Ferrão, R. G. (2001). Variedades clonais de café Conilon para o Estado do Espírito Santo. Pesquisa Agropecuaria Brasileira, 36(5), 765-770. https://doi.org/ 10.1590/S0100-204X2001000500006

Buffon, S. B., Filho, J. A. M., Arantes, L. O., Arantes, S. D., Sant'ana, R. C., Barros, B. L. A., ... Leite, L. A. (2016). Avaliação do crescimento inicial de mudas de café conilon (Coffea canephora) em diferentes acondicionamentos de estacas. In IFES \& INCAPER (Eds.), Anais do I Seminário de iniciação científica e tecnológica (sict) do Incaper, XI Jornada de iniciação científica, desenvolvimento tecnológico e inovação do IFES (PP. 1-4). Venda Nova do Imigrante, IFES.

Cargnelutti Filho, A., Lavezo, A., Bem, C. M., Carini, F., Schabarum, D. E., Bandeira, C. T., ... Neu, I. M. M. (2018). Plot size related to numbers of treatments and replications, and experimental precision in dwarf pigeon pea. Bragantia, 77(2), 212-220. https://doi.org/10.1590/1678-4499.2017085

Celanti, H. F., Schmildt, E. R., Schmildt, O., Alexandre, S. R., \& Cattaneo, F. L. (2016a). Optimal plot size in the evaluation of papaya scions: proposal and comparison of methods. Revista Ceres, 63(4), 469-476. https://doi.org/10.1590/0034-737X201663040006

Celanti, H. F., Schmildt, O., Alexandre, S. R., Cattaneo, F. L., \& Schmildt, E. R. (2016b). Plot size in the evaluation of papaya seedlings 'Baixinho de Santa Amália' in tubes. Revista Brasileira de Fruticultura, 38(3), 1-15. https://doi.org/10.1590/0100-29452016533

Dardengo, M. C. J. D., Sousa, E. F., Reis, E. F., \& Gravina, G. A. (2013). Crescimento e qualidade de mudas de café conilon produzidas em diferentes recipientes e níveis de sombreamento. Coffee Science, 8(4), 500-509.

Dias, R., Melo, B., Rufino, M. A., Silveira, D. L., Morais, T. P., \& Santana, D. G. (2009). Fontes e proporção de material orgânico para a produção de mudas de cafeeiro em tubetes. Ciência agrotécnica, 33(3), 758-764. https://doi.org/10.1590/S1413-70542009000300014

Dickson, A., Leaf, A. L., \& Hosner, J. F. (1960). Quality appraisal of white spruce and white pine seedling stock in nurseries. Forestry Chronicle, 36(1), 10-13. https://doi.org/10.5558/tfc36010-1

Espindula, M. C., Jaraceski, R., Teixeira, A. L., Campanharo, M., \& Dias, J. R. M. (2015). Volume de tubetes para produção de mudas clonais de Coffea canephora 'conilon-brs ouro preto'. IX Simpósio de Pesquisa dos Cafés do Brasil, 24 a 26 de Junho de 2015, Curitiba-PR.

Ferrão, R. G., Fonseca, A. F. A., Ferrão, M. A. G., Verdin Filho, A. C., Volpi, P. S., Muner, L. H., ... Zucateli, F. (2012). Café conilon: técnicas para produção com variedades melhoradas. Revisada e ampliada (Incaper: Circular Técnica, 03-I, 4th ed.). Vitória, ES: Incaper.

Firmino, R. A., Cogo, F. D., Almeida, S. L. S., Campos, K. A., \& Morais, A. R. (2012). Tamanho ótimo de parcela para experimentos com mudas de café Catuai Amarelo 2SL. Revista Tecnologia e Ciência Agropecuária, 6(1), 9-12.

González, G. G. H., Morais, A. R., Bruzi, T. A., Liska, G. R., Reis, C. J., Bortolini, J., \& Sosa, J. H. (2017). Application of the Bootstrap technique in the estimation of optimal plot size in soybean experimente. Tecnología Agraria, 2(1), 36-40.

Hatheway, W. H. (1961). Convenient plot size. Agronomy Journal, 53(4), 279-280. https://doi.org/10.2134/ agronj1961.00021962005300040025x

Lavezo, A., Cargnelutti Filho, A., Alves, B. M., Schabarum, D. E., Silveira, D. L., \& Chaves, G. G. (2018). Plot size and number of replications to assess the vegetable matter in oat. Comunicata Scientiae, 9(2), 252-263. https://doi.org/10.14295/cs.v9i2.2671

Meier, V. D., \& Lessman, K. J. (1970). Estimation of optimum Field plot shape and size for testing yield in Crambe abyssinica Hochst. Crop Science, 11(5), 648-650. https://doi.org/10.2135/cropsci1971.0011183X 001100050013x

Meneghelli, C. M., Monaco, P. A. V. L., Haddade, I. R., Meneghelli, L. A. M., \& Krause, M. R. (2016). Resíduo da secagem dos grãos de café como substrato alternativo em mudas de café conilon. Coffee Science, 11(3), $330-335$.

Oliosi, G., Dalazen, J. R., Covre, A. M., Silva, C. A., \& Partelli, F. L. (2018). Produtividade média de genótipos registrados e promissores de Coffea canephora cultivados no norte do Espírito Santo. In Fundação Procafé 
(Ed), Anais do $44^{\circ}$ congresso brasileiro de pesquisas cafeeiras. Franca, Centro de Convenções do Hotel Dan Inn.

Paranaíba, P. F., Ferreira, D. F., \& Morais, A. R. (2009). Tamanho ótimo de parcelas experimentais: Proposição de métodos de estimação. Revista Brasileira de Biometria, 27(2), 255-268.

Pimentel-Gomes, F. (2009). Curso de estatistica experimental (15th ed.). Piracicaba: Fealq.

$\mathrm{R}$ Core Team. (2019). R: A language and environment for statistical computing. Vienna: R Foundation for Statistical Computing.

Schindelin, J., Rueden, C. T., Hiner, M. C., \& Eliceiri, K. W. (2015). The ImageJ Ecosystem: An Open Platform for Biomedical Image Analysis. Molecular Reproduction and Development, 82(7-8), 518-529. https://doi.org/10.1002/mrd.22489

Schmildt, E. R., Nascimento, A. L., Santos, K. T. H., Malikouski1, R. G., Schmildt, O., Silva, C. A., ... Cuevas, J. (2018). Optimum plot size for experiments with papaya genotypes in field. African Journal of Agricultural Research, 13(8), 360-365. https://doi.org/10.5897/AJAR2017.12951

Schmildt, E. R., Schmildt, O., Cruz, C. D., Cattaneo, L. F., \& Ferreguetti, G. A. (2016). Optimum plot size and number of replications in papaya field experiment. Revista Brasileira de Fruticultura, 38(2), 1-9. https://doi.org/10.1590/0100-29452016373

Silva, J. I., Vieira, H. D., Viana, A. P., \& Barroso D. G. (2010). Desenvolvimento de mudas de Coffea canephora Pierre ex a. Froehner em diferentes combinações de substrato e recipiente. Coffee Science, 5(1), $38-48$.

Storck, L., Garcia, D. C., Lopes, S. J., \& Estefanel, V. (2016). Experimentação vegetal (3rd ed.). Santa Maria: UFSM.

\section{Copyrights}

Copyright for this article is retained by the author(s), with first publication rights granted to the journal.

This is an open-access article distributed under the terms and conditions of the Creative Commons Attribution license (http://creativecommons.org/licenses/by/4.0/). 